\title{
Business Algorithm for the Implementation of Lean Manufacturing Technologies in the Activity of Agro- industrial Enterprises of the Region
}

\author{
Elena Klochko \\ Department of Management \\ Kuban State Agrarian University \\ Krasnodar, Russia \\ E-mail: magadan.79@mail.ru
}

Maria Rybyantseva

Department of Accounting, Analysis and Audit

Kuban State Technological University

Krasnodar, Russia

E-mail: riban1@mail.ru

\author{
Vladimir Novikov \\ Department of State and Municipal Administration \\ Kuban State Technological University \\ Krasnodar, Russia \\ E-mail: vs.novikov@mail.ru
}

Lydia Kovalenko

Department of Management

Kuban State Agrarian University

Krasnodar, Russia

E-mail: kovalenko0801@yandex.ru

\begin{abstract}
The present research is aimed at making provisions on introducing a business algorithm for lean manufacturing technologies implementation into the activity of agro-industrial enterprises of the region. Affected by sanctions, agro-industrial enterprises choose new development thrusts, performant methods to manage operating resources and processes, and effective tools of lean manufacturing. The concept of lean manufacturing provides an extensive set of methods and tools to be considered, implemented and used in various aspects of agro-industrial enterprises' activities. They enable organizing production process, providing goods and services of the required consumer properties in minimum time and at least cost, thereby raising the competitive capacity of business. The commitment to minimizing production losses of agro-industrial enterprises has a key role to play in the implementation of the lean manufacturing concept. In the article, the authors propose a business algorithm for introducing the concept of lean manufacturing in the activity of agro-industrial enterprises of the region.
\end{abstract}

Keywords - lean manufacturing; technology adoption; agroindustrial enterprises; business algorithm; region

\section{INTRODUCTION}

Nowadays, the concept of lean manufacturing suggests an extensive set of methods and practices; however, there is a noticeable problem of their applicability and adaptation to specific production environment of regional agro-industrial enterprises. Generalizing scientific approaches to lean manufacturing, a number of its distinctive features can be identified. Thus, lean manufacturing is related to logistical management, which focuses on targeted reduction in production lot-sizes. Reducing stock limits of resources and continuous staff development are also considered an integral part of lean manufacturing, as well as applying flexible management technologies to production processes and integrating them into the associated technologies of subcontractory companies. Today, lean manufacturing is represented by a synthesis of European and American management practices.

Generally, the agricultural regions of Russia (for instance, Krasnodar Krai), demonstrate a positive trend in terms of their attitude and commitment towards lean manufacturing and its application. An increasing number of agro-industrial enterprises introduce new or optimized production systems; some have already reached positive dynamics in costs. One of the issues of lean manufacturing implementation is the lack of information and its insufficient adaptation to specific economic features of agro-industrial regions.

Executives of agro-industrial enterprises of the region also mention the lack of professionals in the field of lean manufacturing, which necessitates training such specialists or attracting them to enterprises.

In their works, researchers Forrester P.L., Shimizu U.K., Soriano-Meier H., Garza-Reyes J.A., Basso L.F.C. [3], Bergman E.M., Feser E.J., Kaufmann A. [1] highlighted the issues of lean technologies and their influence on the upward trend in key social and economic indicators, as well as in agro-industrial complex indicators. The basis of the present study is represented by the developments of Womack J.P., Jones D.T. [9], Macduffie J.P., Helper S. [5], Hampson Ia. [4], who investigated economic processes and management approaches of introducing lean manufacturing tools and technologies. At the time, Cai A., Yang S. [2] studied the problems of risk management in the process of lean manufacturing implementation. 


\section{RESULTS}

The issues of human capital and human resources management were touched upon in the works by Parker Sh.K. [6], Rutherford T.D. [7], Saurin T.A., Marodin G.A., Ribeiro J.L.D. [8].

The hypothesis of the research is that sustainability of the microeconomic system (an agro-industrial enterprise) is largely determined by the interaction of internal and external environments, based on modernizing approaches and technologies of managing production changes, with the account taken of specific scientific, technical and innovative nature of the system elements. The solution to this problem is in developing agro-industrial enterprises management through lean production, studying the efficiency of the applied methods and tools and strategic mapping to ensure adaptability to external changes and both mid-term and longterm progressive development.

\section{METHODS}

Theoretical and methodological foundation of the research is represented by the institutional approach to investigating the problems of production management in agro-industrial enterprises; the system approach, including the classical, evolutionary and co-evolutionary directions; the theory of industrial organization. These concepts served the basis for the formation of the authors' viewpoint on the implementation of lean manufacturing approaches in the activity of agro-industrial enterprises. In order to attain the envisaged goals, such methods as graphical tabular methods of data analysis, as well as building and describing process models, were used.

Nowadays, it is clear that Russian experience is significantly different from the experience of European countries. In fact, the activity of Russian agro-industrial enterprises is mostly focused on lean manufacturing tools, while foreign enterprises are more concerned with forming ideological aspects of lean manufacturing and corporate culture. In this respect, it should also be mentioned that it is impossible to achieve positive results of lean manufacturing without lean manufacturing ideology. Therefore, it is critical to create the corporate culture that will encourage lean manufacturing implementation. The elements of corporate culture require leaders and their teams to demonstrate wellhoned work and proper behaviour within the production process. Thus, a leader being the "locomotive" (correct ideological thinking), forms the "train set", introducing the tools of lean manufacturing into the activity of an agroindustrial enterprise. The ideology of lean manufacturing involves formation and development of lean and consistent optimization of business processes (with maximum industry orientation or focus on the market, taking into account employee motivation). According to our opinion, mission development and setting specific goals and objectives for each agro-industrial enterprise under consideration is of particular importance when implementing the concept of lean manufacturing.
The problems that arise when introducing lean manufacturing into the activity of agro-industrial enterprises of the region are limited to three reasons.

The first reason is channelling efforts to implement lean manufacturing approaches into one selected aspect of the company's functioning only. For example, when the management introduces changes to improve material flow exclusively. It results in the management of all enterprise divisions neglecting the non-material part of production: corporate culture, human resources and their development, information management and office work and document control optimization.

The second reason is the insufficient engagement of all teams and structural divisions of an agro-industrial enterprise when implementing the lean manufacturing concept. It means that one group of stakeholders is engaged in optimizing and implementing approaches of lean manufacturing, while others perform supervisory function only and are not interested in the shared goal of lean manufacturing. Meanwhile, everybody's involvement in the improvement process is one of the first and basic principles of the lean manufacturing concept.

The third reason is related to staff motivation of all teams and divisions of agro-industrial enterprises when introducing improvements according to the concept of lean manufacturing. The management of an agro-industrial enterprise has to assess its employees from the perspective of their readiness to adopt the concept of lean manufacturing.

Then the management of an agro-industrial enterprise should divide all the existing employees into the following categories:

- Those who are willing to change and know how to introduce changes (they are potential leaders to develop a company).

- Those who are willing to change, but do not know how to introduce changes (they may become leaders, but there should be personal training conducted).

- Those who are not willing to change, but know how to implement changes (they are managers and regular employees with insufficient motivation, they need to understand clearly why introduce changes to the activity of an agro-industrial enterprise).

- Those who are neither willing to change, nor know how to introduce changes (such employees lack motivation and professional knowledge, impede improvement process and optimization processes, resist any, even simple and logical changes).

It is also important to emphasize the following managerial aspect: the correlation between the number of employees and subordinates in groups has a significant influence on how long and strongly enterprise staff will resist changes. There are several recommendations that may help to transfer all employees of an agro-industrial enterprises to the "willing to change and know how" group. They include: 
methodology, employees are free to decide on how to perform their work conveniently.

- Training, which is essential both at the initial stages of implementation and after. People represent the most valuable assets of any company. Training increases the efficiency of the agro-industrial enterprise.

- Management participation. Everyone should be involved in the improvement process; what is more, it is managers, who should lead and serve as examples for other workers to follow.

Following the above mentioned recommendations, the agro-industrial enterprise will be able to solve the problems that arise when introducing and implementing the concept of lean manufacturing.

We outline the steps that are to be made by the management of an agro-industrial enterprise towards the successful implementation and application of lean manufacturing tools. "Fig. 1" represents the proposed algorithm for the implementation and application of the tools of the lean manufacturing concept.

- Delegating authority when implementing the methods and tools of the lean manufacturing concept. In order for employees to realize their importance in the activity of the agro-industrial enterprise, they should be provided with an opportunity to make independent decisions. For instance, when implementing the $5 \mathrm{~S}$ 
Deciding on the need for a new concept

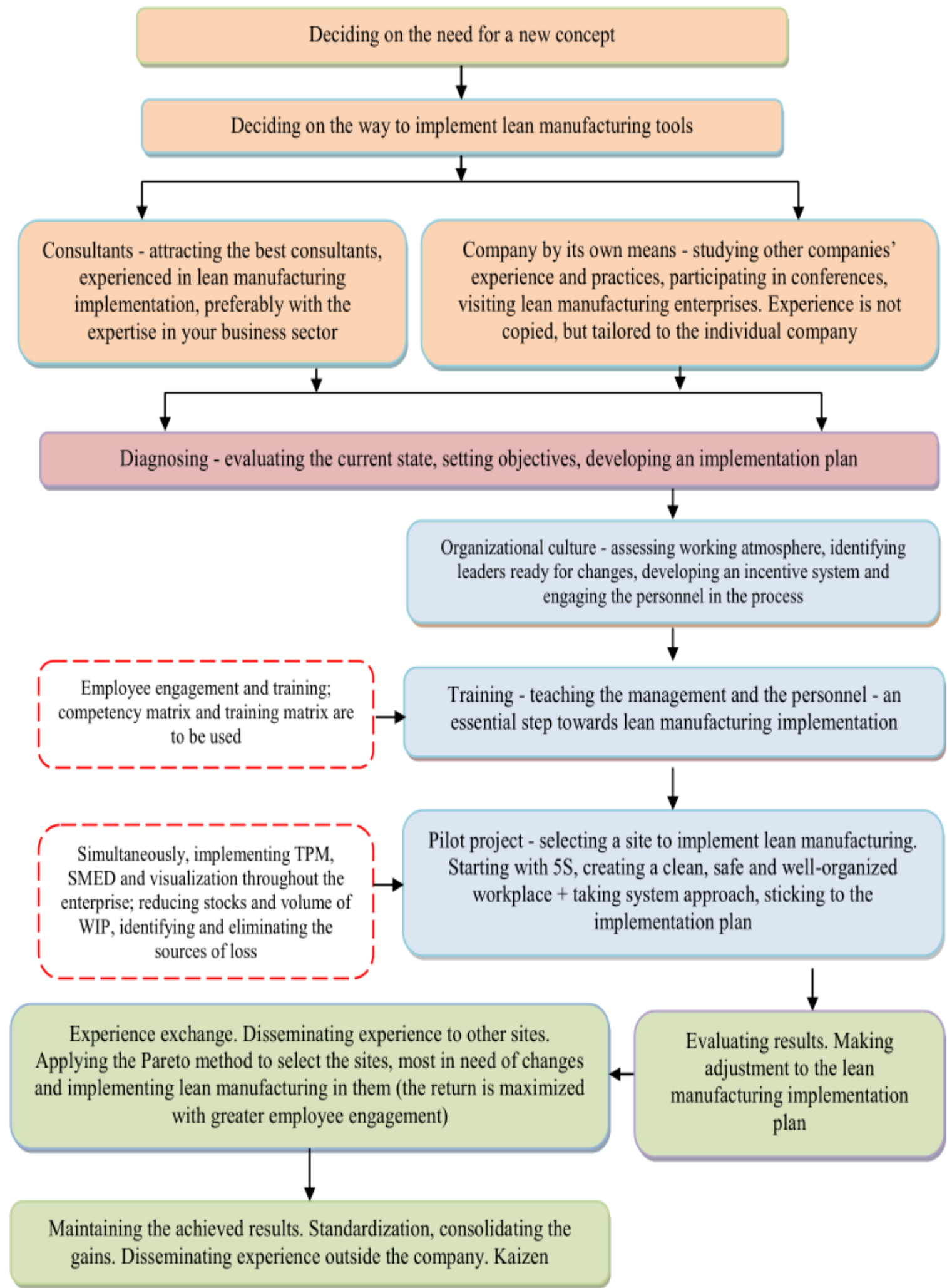

Fig. 1. Business algorithm for the implementation of lean manufacturing in the activity of an agro-industrial enterprise.

Let us consider the stages of lean manufacturing tools implementation and application. The first stage implies making a decision on the need for a new production system in an agro-industrial enterprise. Most often, the management of the enterprise come up with this solution, when in a challenging situation (crisis, the need to increase competitiveness, reduce costs, etc.). 
the agro-industrial enterprise depends not only on internal, but also on external factors. Disseminating experience in the activities of subcontractory companies will provide positive results. Thus, suppliers may implement the Just-in-time (JIT) system to reduce stocks.

Kaizen: The management of the agro-industrial enterprise should not neglect its continuous improvement. The goals of the agro-industrial enterprise should be periodically reviewed to identify development thrusts in management and lean manufacturing. The concept of lean manufacturing presupposes continuous enhancement of the entire management of the agro-industrial enterprise. It is not a one-time project, but a new style of management.

The described stages are universal for any agro-industrial enterprise of the region. Nevertheless, the approaches of lean manufacturing should be adjusted with the account taken of the goals of individual agro-industrial enterprise and the sector where it functions.

Accordingly, the main task of the management of an agro-industrial enterprise when introducing and implementing the concept of lean manufacturing is the work with the personnel. In this respect, the executives of an agroindustrial enterprise should perform the following functions:

- Provide employees with access to all the necessary information regarding the goals of the agro-industrial enterprise, the results of the new strategy implementation and plans for the future;

- Be leaders. Participate in transformations, solve problems in the field, keep updated on transformations;

- Identify and encourage status leaders, reward them for efforts towards introducing the concept of lean manufacturing; involve status leaders in the process of integrating the tools of the concept;

- Participate personally in several projects (at least) so that employees have examples to follow;

- Help employees self-develop and improve managing the agro-industrial enterprise;

- Motivate the personnel through competitions, business games, meetings, corporate events;

- Assess the level of staff engagement on a regular basis and conduct engagement activities;

- See problems as opportunities to grow and abolish penalties for mistakes.

When introducing the concept of lean manufacturing into the activity of a regional agro-industrial enterprise, there should be consistency of steps and actions. For example, if the management of an agro-industrial enterprise has not yet solved the problem of motivation and performed the initial actions to introduce the concept of lean production, the results from the further steps will be minimal or will not be present all. That is why, applying the concept of lean the "supplier - agro-industrial enterprise - consumer" Assisting other enterprises in the implementation and application of lean manufacturing tools. The performance of 


\section{REFERENCES}

manufacturing, the management of an agro-industrial enterprise is to go through all the described stages.

\section{DISCUSSION}

To conclude, the concept of lean manufacturing should be implemented at all management levels and in all divisions of an agro-industrial enterprise. Any division employee can put forward proposals on improving production processes, which in their turn should be objectively and timely considered and immediately introduced into everyday activities, in case of a positive decision made. It is also critical to consider the fact that at the present stage of production development in agro-industrial enterprises, process changes made in one company unit result in the need to rebuild processes throughout the company, even if benefit are not obvious. The introduction and implementation of such procedures and changes creates additional responsibilities for managers of agro-industrial enterprises and can be met with resistance, at least at the initial stages of implementation.

Besides, full operation of such a system requires a welldeveloped interaction between the agro-industrial enterprise and its counterparties - contractors, suppliers and customers. A lean production enterprise requires timely and minimumlot deliveries. Obviously, such requirements can only be met by large customers, able to impose conditions on their suppliers.

It should be taken into consideration that if a supplier is a monopolist or the choice of suppliers is limited, it is difficult to cooperate with, even for large customers. It may lead to problems with efficiency, uninterrupted operation and quality of deliveries. Among other things, it is necessary to clearly synchronize the data on available stocks, production plans and procurement plans of the agro-industrial enterprise and its counterparties.

\section{CONCLUSION}

The results of the study allow us to make the following conclusions:

The management of agro-industrial enterprises should focus on problems inextricably linked and associated with the need for lean manufacturing changes the corporate culture, such as lack of understanding of the concept, indifference of the personnel and management, lack of planned objective motivation.

An important managerial aspect has been outlined: the correlation between the number of employees and subordinates in groups has a significant influence on how long and strongly the enterprise staff will resist changes.

The stages of implementing lean manufacturing technologies in the activity of an agro-industrial enterprise have been identified and proposed in the form of a business algorithm.
[1] Bergman E.M., Feser E.J., Kaufmann A. Lean production systems in regions: conceptual and measurement requirements // The Annals of Regional Science. 1999. T. 33. No. 4. Pp. 389-423.

[2] Cai A., Yang S. Risk analysis of the production line type design based on the lean production // Applied Mechanics and Materials. 2011. No. 44-47. Pp. 56-60.

[3] Forrester P.L., Shimizu U.K., Soriano-Meier H., Garza-Reyes J.A., Basso L.F.C. Lean production, market share and value creation in the agricultural machinery sector in Brazil // Journal of Manufacturing Technology Management. 2010. T. 21. No.7. Pp. 853-871.

[4] Hampson Ia. Lean production and the Toyota production system or, the case of the forgoften production concepts // Economic \& Industrial Democracy. 1999. T. 20. No. 3. Pp. 369-391

[5] Macduffie J.P., Helper S. Creating lean suppliers: diffusing lean production through the supply chain // California Management Review. 1997. T. 39. No. 4. Pp. 118-151.

[6] Parker Sh.K. Longitudinal effects of lean production on employee outcomes and the mediating role of work characteristics // Journal of Applied Psychology. 2003. T. 88. No. 4. Pp. 620-634.

[7] Rutherford T.D. Convergence, the institutional turn and workplace regimes: the case of lean production // Progress in Human Geography. 2004. No. 28. No. 4. Pp. 425-446.

[8] Saurin T.A., Marodin G.A., Ribeiro J.L.D. A framework for assessing the use of lean production practices in manufacturing cells // International Journal of Production Research. 2011. No. 49. №11. Pp. 3211-3230.

[9] Womack J.P., Jones D.T. From lean production to lean enterprise // Harvard Business Review. 1994. T. 72. No. 2. Pp. 93-103. 